\title{
In Memoriam Professor Ülo Kaevats
}
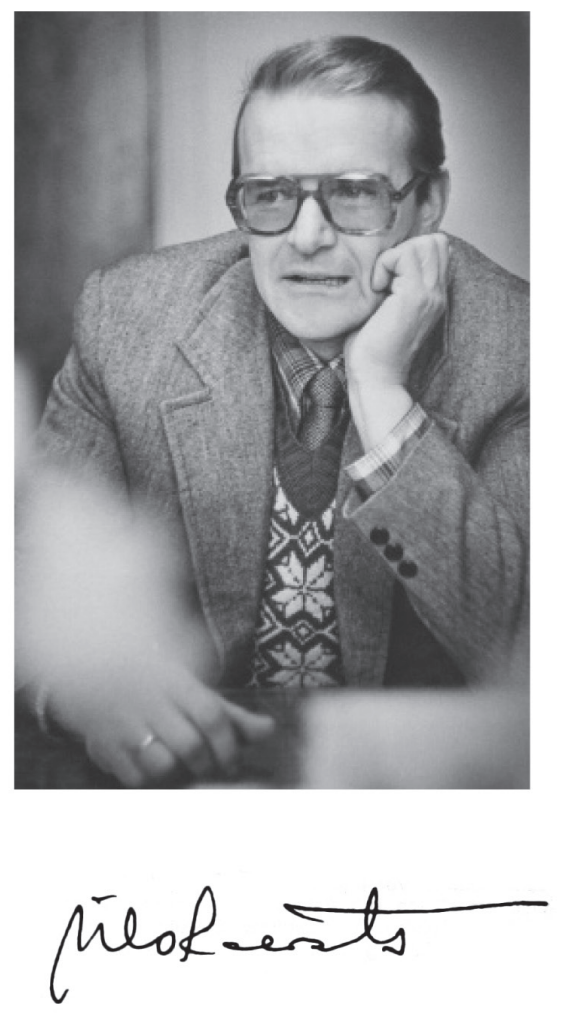

29.09.1947 - 30.01.2015 
Ülo Kaevats, born on 29 September 1947 in Kassari, Hiiumaa, passed away on 30 January 2015. He was Professor Emeritus of the Tallinn University of Technology and a board member of the Estonian Association for the History and Philosophy of Science. Professor Kaevats, educated as a physicist at the Tartu State University (1972), specialized in the philosophy of science. He worked as research fellow at the Institute of History of the Estonian Academy of Sciences (1973-1981) and as associate professor at the professorial Chair of Philosophy (1981-1989). ${ }^{1}$ Kaevats earned his Candidate of Philosophy degree (equivalent of today's PHD) from the Vilnius State University (1981). In 1999, he became Head of the Chair of Philosophy at the Tallinn University of Technology and was elected Professor of Philosophy of Science. In 20002004, he served as Director of the TUT Department of Humanities and Social Sciences. Kaevats became professor emeritus in 2011, after which he carried on participating in the activities of the Chair of Philosophy and lecturing in the fields of philosophy of science and political philosophy until early 2015. Students and colleagues all recognized his warm personality and his skills as a splendid lecturer and educator.

Ülo Kaevats's death was a great loss—not only to the sectors of Estonian higher education but also to the public life, which lost one of its most active and conscientious members. It is impossible to overestimate his services to the Republic of Estonia during the turbulent times and throughout the period of regaining Estonian independence. During the Singing Revolution, he was one of the chief architects of the Estonian republic, especially as Head of the Programme Committee of the Popular Front (1988-1990). His leading role in political and social life continued after the restoration of independence, among others, as Secretary of State (1992-1995). At that time the position indeed had a much greater weight in the Estonian political life than what it may be today.

No nation can affirm its cultural and intellectual status without having an encyclopaedia produced in its native language. Ülo Kaevats served as Editorin-Chief of the Estonian Encyclopaedia for many years (1989-1992, volumes 5-7; and 1995-2000, volumes 8-10).

The professorial Chair of Philosophy was established at the Academy of Sciences of the Estonian SSR to teach the course in philosophy mandatory for those who applied for a scientific degree within the system of the Academy of Sciences. 
After the stabilisation of the Estonian State and its public sector, Kaevats returned to the philosophy of science, his main field of research and a life-long passion. Under his lead, the Chair of Philosophy at the Tallinn University of Technology became an important centre for academic philosophy in Estonia to specialize in the philosophy of science, technology and the social sciences. Yet Ülo the academic did not withdraw from public life, constantly keeping an eye on significant developments in society and actively expressing his views in the media and at public events. But his attention was now increasingly more on consolidating the position of the Tallinn University of Technology in the landscape of higher education in Estonia. Kaevats was actively involved in developing and drafting the basic legal, administrative and academic framework essential for a modern university of technology, and served as a skilled moderator at the university management.

Ülo Kaevats's research in the philosophy of science dates back to the Soviet era and was largely published in Russian. His dissertation on the methodology of science, entitled Thought Models in the Formation and Functioning of Scientific Theory (Gnoseological Analysis) was supervised by Lembit Valt (1934-2008), the founder of philosophy of science in Estonia. At that time Kaevats wasin addition to his supervisor's work on the thought models-exploring the practice-based approach to the philosophy of science developed in the Soviet Union, including Estonia, within a certain community of philosophers of science, although this approach was considered heretical from the point of view of the official Soviet philosophy. Today the practice-based approach has become one of the most prevalent and dynamic approaches among contemporary philosophers of science. The approach had already emerged in the 1970s, as witnessed by the work of Vyacheslav S. Stepin (born 1934), director of the Institute of Philosophy at the USSR/Russian Academy of Sciences in 19882006, who published the book Formation of Scientific Theory: Substantive Aspects of the Genesis and Structure of Physics-Theoretical Knowledge (Minsk, 1976), ${ }^{2}$ and which became the main source for Kaevats's dissertation. ${ }^{3}$ Together with

2 This book is still topical—as Ülo Kaevats himself has pointed out in his foreword to Rein Vihalemm's book Teadusfilosoofilisest vaatepunktist ('From the Point of View of the Philosophy of Science'; 2008) in the preparation process of which he was involved - an English version of the book was published in 2005 in the Synthese Library series (V. Stepin, Theoretical Knowledge, Dordrecht: Springer).

3 The collection, with Valt as one of the authors, was published in Estonian (editor R. Vihalemm, Teaduse metodoloogia ('Methodology of Science'), 1979). The collection largely discussed the practice-based approach to scientific theories, which Ülo Kaevats in his review of this book drew attention to (Looming, 1980, pp. 739-740, see also Ü. Kaevats \& O. Podlishevski, Filosofskie nauki, 1982, pp. 181-183). 
Rein Vihalemm, Stepin was Kaevats's opponent at the dissertation defence. During the period of writing his dissertation, Kaevats published, in Russian, three substantial research papers and short articles on his talks he delivered at philosophy conferences. ${ }^{4}$ The author's contribution was the integration of the theme of scientific modelling, fairly well explored already at that time, with the issues of how physical theories are developed from the points of view of thought models and thought experiments: the kind of integrated research had not been undertaken before but it blended in with Stepin's practicebased approach. Kaevats joined the authors who drew attention to the rather one-sided understanding of scientific theories as hypothetical-deductive. The constructive role of thought modelling and experimentation became apparent under the practice-based approach. It also shed new light on the so-called problem of visualisation - another major current in contemporary philosophy of science-which at that time had caused difficulties in the traditional reflection-representational approach. Kaevats's work also became known as having proposed a new name for such updated models of what the scientific theories are: hypothetico-constructive-deductive theory. ${ }^{5}$

Kaevats was a member of the advisory board of Studia Philosophica Estonica and the Council of the Institute of Philosophy and Semiotics of the University of Tartu. He was an active member of the Estonian Association for the History and Philosophy of Science, gave talks at its conferences and published results, among others, in its series Teaduslugu ja nü̈̈disaeg ('Science Studies Today'). ${ }^{6}$ His last substantial article in the field of philosophy of science was an essayistic "Scientia est potentia" (Studia Philosophica Estonica, 1.3, 2008, pp. 43-60). He exercised his encyclopaedic interests as an author of short articles on philosophy (400) in Väike entsüklopeedia ('Small Encyclopaedia', Tallinn, 2006), was among the authors of the glossary on education Haridusleksikon (2013, editor

The three papers were: 'On constructing logical-mathematical models of theories of physics,' in Metod modelirovaniia i nekotorye filosofskie problemy istorii i metodologii estestvoznaniia, Tallinn: Estonian Academy of Sciences, 1975, pp. 87-96; 'Interaction between conceptual and visual in theory of physics', Proceedings of the Estonian Academy of Sciences. Social Sciences, 1979, 28(4), pp. 334-346; and 'An addition to the hypotheticodeductive theory,' Acta et Commentationes Univesitatis Tartuensis, 465. Trudy po filosofii, XX, 1979, pp. 14-27. 5 See also: 'A hypothetico-constructive-deductive model of knowledge' (in Russian, materials of the $8^{\text {th }}$ AllUnion Conference "The Logic and Methodology of Science", Vilnius, 1982); collection Struktura i razvitie nauchnogo znaniia. Sistemnyi podkhod k metodologii nauki, Moscow, 1982, pp. 92-95.

6 'Scientific and philosophical aspect of scientific research' (I, 1979, pp. 223-229); 'Science as a component of culture' (II, 1982, pp. 23-30); 'On the rationality of science' (III, 1984, pp. 113-119); 'On the role of the methodology of science in the science studies of the Estonian SSR' (co-author M. Remmel, IV, 1987, pp. 137-147); 'The concept of truth in the $20^{\text {th }}$-century philosophy of science' (XI, 2007, pp. 137-150). 
Rain Mikser) and convened its working group. He wrote a number of popular and public writings, reviews and socio-political essays and actively served as an expert in committees and as member of the editorial boards of the Proceedings of the Rigikogu and Haldusjuhtimine ('Public Administration'). He was also preparing a philosophy of science textbook designed for those MA and $\mathrm{PHD}$ students whose major was not philosophy; it was especially targeted at students of engineering and social sciences to provide guidance on coping with the everincreasing complexities of the future world. Regrettably, his plan remained unrealized.

The warm memory of Ülo Kaevats—a philosopher, a statesman, a good colleague, a companion and a friend—will remain with all of us.

Rein Vihalemm

Peeter Mü̈rsepp

Ahti-Veikko Pietarinen 